\title{
Peningkatan Kemampuan Pemahaman Konsep Melalui Pembelajaran Berbasis Masalah
}

\author{
Fitrianto Eko Subekti ${ }^{1}$, Budi Priyanto ${ }^{2}$ \\ ${ }^{l}$ Fakultas Keguruan dan Iilmu Pendidikan, Universitas Muhammadiyah Purwokerto \\ ${ }^{2}$ SMK Muh. 3 Purwokerto \\ Email : ${ }^{1}$ efitrians@ymail.com, ${ }^{2}$ zakifakih64@gmail.com
}

\begin{abstract}
This research aims to increase the ability in concept comprehension of the students class XII Farmasi B SMK Muhammadiyah Purwokerto on statistics. It is carried out in three cycles. In which each end of the cycle is carried out on evaluation to measure the ability of the students concept comprehension. The data of the concept comprehension is taken using a test. This data, then showed on a mean form. The result of the evaluation shows that there is an increasing from cycle 1 to cycle II, and from cycle II to cycle III. The mean of cycle I = 70, cycle $\mathrm{II}=75$ and cycle III $=78$. Based on the above result, it can be concluded that throught learning based on problem thr ability in concept comprehension can be increased.
\end{abstract}

Keyword: concept comprehension, problem based learning, statistic.

Abstrak.Penelitian ini bertujuan untuk meningkatkan kemampuan pemahaman konsep siswa kelas XII Farmasi B SMK Muhammadiyah Purwokerto pada materi statistika. Penelitian dilaksanakan dalam 3 siklus, dimana setiap akhir siklus dilaksanakan evaluasi untuk mengukur kemampuan pemahaman konsep siswa. Data pemahaman konsep diambil melalui tes. Data tersebut, kemudian di disajikan dalam bentuk rata-rata. Hasil menunjukan terjadi peningkatan dari siklus I ke siklus II, dan peningkatan dari siklus II ke siklus III. Adapun ratarata pada siklus I = 70; siklus II = 75; dan siklus III $=78$. Berdasarkan hasil tersebut dapat dikatakan bhawa melalui pembelajaran berbasis masalah kemampuan pemahaman konsep dapat ditingkatkan.

Kata kunci: pemahaman konsep, pembelajaran berbasis masalah, statistik.

\section{PENDAHULUAN}

Matematika tidak hanya sekedar pemahaman dalam menyelesaikan soal akan tetapi memiliki peran penting yang dibutuhkan dalam kehidupan sehari-hari. Hampir setiap aktivitas dan pekerjaan membutuhkan matematika. Ada dua visi dalam pembelajaran matematika, yaitu: mengarahkan pembelajaran matematika untuk memahami konsep matematika yang kemudian digunakan untuk menyelesaikan permasalahan yang lainnya; dan matematika mendorong untuk berkembangnya kemampuan bernalar, kritis, sistematis, cermat, dan kreatif serta menumbuhkan rasa percaya diri dan mampu beradaptasi dalam menghadapi kehidupan yang selalu berubah (Sumarmo, 2010).

Berdasarkan visi pembelajaran matematika tersebut, salah satu kemampuan yang harus dikuasai adalah kemampuan pemahaman konsep matematis. Kemampuan pemahaman konsep matematis merupakan kemampuan dasar sebelum seseorang menguasai kemampuan-kemampuan yang lain. Untuk memecahkan masalah matematis dan 
mengkomunikasikannya, seseorang harus memahami konsepnya terlebih dahulu.

Menurut Sudijono (2009), seorang siswa dikatakan memahami sesuatu jika ia dapat memberikan penjelasan yang lebih rinci dengan bahasanya sendiri. Sedangkan konsep menurut Wardhani (2008) adalah ide abstrak yang memungkinkan seseorang untuk menggolongkan suatu objek. Menurut Zacks \& Tversky, konsep adalah kategorikategori yang mengelompokkan obyek, kejadian, dan karakteristik secara umum (Santrock, 2010).

Pemahaman konsep merupakan kompetensi dalam memahami konsep dan melakukan prosedur secara luwes, akurat, efisien, dan tepat (Peraturan Dirjen Dikdasmen No. 506/C/PP/2004). Selain itu siswa mampu mendefinisikan, mengidentifikasi, dan memberi contoh atau bukan contoh dari konsep yang diberikan (Shadiq, 2009).

Sedangkan menurut Wardhani (2008), memahami konsep matematika berarti menjelaskan keterkaitan antarkonsep dan melakukan atau mengaplikasikan prosedur (algoritma) secara luwes, akurat, efisien, dan tepat dalam pemecahan masalah. Dengan demikian dapat dikatakan bahwa pemahaman konsep telah dikuasai oleh siswa jika siswa mampu mendefinisikan konsep dan menggunakan ide-ide yang saling berhubungan untuk menyelesaikan permasalahan yang diberikan. Sedangkan siswa dikatakan memahami prosedur jika mampu mengenali prosedur (sejumlah langkah-langkah kegiatan yang dilakukan) yang di dalamnya termasuk aturan algoritma atau proses menghitung dengan benar. Pemahaman konsep akan berkembang apabila guru dapat membantu siswa mengeksplorasi topik secara mendalam dan memberi mereka contoh yang tepat dan menarik dari suatu konsep (Santrock, 2010).
Berdasarkan hasil observasi di kelas XII Farmasi B, terlihat bahwa beberapa siswa masih kesulitan dalam menggunakan rumus luas daerah pada integral tentu. Mereka terlihat kebingungan untuk memilih rumus mana yang digunakan. Selain itu siswa masih kesulitan ketika siswa diberikan soal yang berbeda dengan contoh sebelumnya. Jika soal yang diberikan dimodifikasi, mereka terlihat kebingungan untuk menyelesaikanya.

Gejala-gejala tersebut dapat diduga bahwa kemampuan pemahaman konsep siswa masih rendah. Untuk itu peneliti ingin meneliti tentang menerapkan pembelajaran berbasis masalah untuk meningkatkan kemampuan pemahaman konsep siswa. Hal ini sejalan dengan pendapatnya Barbara (2001) yang menyatakan bahwa pembelajaran berbasis masalah dapat digunakan untuk segala usia, tingkat perkembangan dan segala disiplin ilmu. Selain itu dalam pembelajaran berbasis masalah berfokus pada solusi dari permasalahan dan guru lebih berperan sebagai fasilitator.

Menurut Barrow (Huda, 2013) Pembelajaran Berbasis Masalah merupakan pembelajaran yang menekankan pemahaman melalui berbagai pendapat untuk mendapatkan solusi terhadap masalah yang diberikan. Sedangkan menurut Cahyo (2013) Pembelajaran Berbasis Masalah merupakan suatu pembelajaran yang menekankan pada prinsip penggunaan masalah sebagai awal untuk mendapatkan pengetahuan yang baru. Dengan demikian dapat dikatakan bahwa Pembelajaran Berbasis Masalah merupakan pembelajaran yang diawali dengan masalah untuk merangsang siswa dalam menyelesaikan masalah tersebut. Dalam pembelajaran ini permasalahanpermasalahan dipilih dan dirancang dengan cermat yang menuntut upaya kritis siswa untuk memperoleh pengetahuan, 
menyelesaikan masalah, belajar secara mandiri dan memiliki keterampilan partisipasi yang baik.

Proses pembelajaran berbasis masalah (PBL) pada dasarnya terdiri dari tahaptahap berikut: (1) menemui masalah; (2) analisis masalah ; (3) penemuan dan pelaporan; (4) presentasi dan refleksi; dan (5) gambaran umum, integrasi, dan evaluasi yang menjembatani satu tahap dan tahap berikutnya (Tan, 2003). Hal ini sejalan dengan Arend (Sutawidjaja, 2011) Pembelajaran Berdasarkan Masalah memiliki lima fase penting, seperti pada tabel di bawah ini.

Tabel 1 Fase-fase Pembelajaran Berbasis Masalah

\begin{tabular}{l|l}
\hline \multicolumn{1}{c}{ Fase-fase } & \multicolumn{1}{c}{ Kegiatan guru } \\
\hline $\begin{array}{l}\text { Fase 1 : Orientasi siswa } \\
\text { kepada masalah }\end{array}$ & $\begin{array}{l}\text { Guru menjelaskan tujuan pembelajaran, menjelaskan perangkat } \\
\text { yang dibutuhkan, memotivasi siswa agar terlibat pada aktivitas } \\
\text { pemecahan masalah yang dipilihnya }\end{array}$ \\
\hline $\begin{array}{l}\text { Fase 2: Mengorganisasi siswa } \\
\text { untuk belajar }\end{array}$ & $\begin{array}{l}\text { Guru membantu siswa mendefinisikan dan mengorganisasikan } \\
\text { tugas belajar yang berhubungan dengan masalah yang tersebut }\end{array}$ \\
\hline $\begin{array}{l}\text { Fase } 3: \text { Membimbing } \\
\text { penyelidikan individual dan } \\
\text { kelompok }\end{array}$ & $\begin{array}{l}\text { Guru mendorong siswa untuk mengumpulkan informasi yang } \\
\text { sesuai dan melaksanakan eksperimen untuk mendapatkan } \\
\text { penjelasan serta pemecahan masalahnya }\end{array}$ \\
\hline $\begin{array}{l}\text { Fase4 : Mengembangkan dan } \\
\text { menyajikan hasil karya }\end{array}$ & $\begin{array}{l}\text { Guru membantu siswa merencanakan dan menyiapkan karya } \\
\text { dengan temannya }\end{array}$ \\
\hline $\begin{array}{l}\text { Fase 5 : Merefleksi dan } \\
\text { mengevaluasi proses } \\
\text { penyelesaian masalah }\end{array}$ & $\begin{array}{l}\text { Guru membantu siswa melakukan refleksi atau evaluasi terhadap } \\
\text { penyelidikan mereka dan proses -proses yang mereka gunakan }\end{array}$ \\
\hline
\end{tabular}

Berdasarkan latar belakang yang dipaparkan di atas, permasalahan yang diajukan adalah "Apakah melalui Pembelajaran Berbasis Masalah kemampuan pemahaman konsep siswa kelas XII Farmasi B SMK Muhammadiyah 3 Purwokerto dapat ditingkatkan?".

\section{METODE}

Jenis penelitian yang dilakukan oleh peneliti adalah Penelitian Tindakan Kelas. Penelitian dilaksanakan untuk meningkatkan kemampuan pemahaman konsep siswa melalui Pembelajaran Berbasis Masalah. Penelitian dilaksanakan dalam 3 siklus, dimana siklus pertama terdiri atas 4 kali pertemuan, siklus kedua dan ketiga masing-masing dua kali pertemuan. Di akhir setiap siklus selama 1 jam pelajaran digunakan sebagai evaluasi akhir siklus. Penelitian dilaksanakan pada bulan Agustus s.d. September 2018 dengan mengambil subyek kelas XII Farmasi B SMK Muhammadiyah Purwokerto.

Adapun prosedur untuk tiap siklus terdiri atas: (a) perencanaan; (b) pelaksanaan; (c) observasi dan evaluasi; serta (4) refleksi. Dalam tahap perencanaan, peneliti membuat rencana program pembelajaran yang akan digunakan selama kegiatan belajar mengajar. Tahap yang dilakukan adalah sebagai berikut : (a) Membuat perangkat pembelajaran berupa Rencana Pelaksanaan Pembelajaran (RPP) dengan menggunakan model Pembelajaran Berbasis Masalah dan Lembar Kerja Peserta Didik (LKPD); dan (b) Membuat instrumen penelitian berupa kisi-kisi soal evaluasi, 
jurnal refleksi pembelajaran, dan tes evaluasi kemampuan pemahaman konsep siswa.

Setelah semua persiapan selesai, pelaksanaan tindakan kelas mengacu pada RPP yang telah disusun. Guru melakukan aktivitas pembelajaran menggunakan model Pembelajaran Berbasis Masalah. Langkah selanjutnya adalah observasi dan evaluasi. Kegiatan observasi dilakukan untuk mengamati aktivitas proses pembelajaran serta mengetahui kemampuan pemahaman konsep siswa. Dalam hal ini yang menjadi observer adalah guru mata pelajaran matematika kelas XII Farmasi B SMK Muhammadiyah 3 Purwokerto. Sedangkan Evaluasi ini dilakukan pada akhir siklus yang digunakan untuk tolak ukur pelaksanaan pembelajaran pada setiap siklusnya. Refleksi merupakan kegiatan yang dilakukan untuk menganalisis hasil observasi, baik kelemahan, maupun kelebihan dari pembelajaran yang sudah dilakukan. Pada tahapan ini semua hasil observasi dan evaluasi diolah dan direflesikan untuk mengukur tingkat keberhasilan dan mengetahui kelemahan pelaksanaan tindakan selama satu siklus berlangsung, kemudian merencanakan tindakan untuk siklus selanjutnya.

Data penelitian ini didapatkan melalui tes dan observasi. Tes digunakan untuk mengukur kemampuan pemahaman konsep siswa dan dilaksanakan pada setiap akhir siklus. Model tes yang digunakan adalah tes uraian, karena model tes uraian dapat mengembangkan daya pikir siswa untuk menyelesaikan masalah sehingga dapat mengukur kemampuan pemahaman konsep siswa. Sedangkan observasi dilakukan untuk mengumpulkan data pelaksanaan pembelajaran menggunakan model Pembelajaran Berbasis Masalah. Observasi pelaksanaan pembelajaran menggunakan jurnal refleksi pembelajaran. Data hasil tes kemudian disajikan dalam bentuk rata-rata dan data hasil observasi kemudian dideskripsikan secara kualitatif. Indikator keberhasilan pada penelitian ini yaitu apabila terjadi peningkatan kemampuan pemahaman konsep siswa dari siklus 1 hingga siklus 3 yang ditandai dengan adanya peningkatan skor rata-rata kemampuan pemahaman konsep siswa dari siklus 1 hingga siklus 3 .

\section{HASIL DAN PEMBAHASAN}

Penelitian tindakan kelas ini dilaksanakan dalam 3 siklus. Pada siklus I terdiri atas 4 pertemuan, sedangkan pada siklus 2 dan 3 terdiri dari dua kali pertemuan dengan alokasi waktu kegiatan belajar mengajar 2 jam pelajaran $(2 \times 40$ menit). Pada setiap akhir siklus dilaksanakan tes evaluasi selama 1 jam pelajaran (1 x 40 menit). Tes evaluasi digunakan untuk mengetahui kemampuan pemahaman konsep siswa. Berikut ratarata nilai kelas XII Farmasi B siklus I, II, dan Siklus III.

Tabel 2. Rata-rata pemahaman konsep tiap siklus

\begin{tabular}{cc}
\hline Siklus & Rata-rata \\
\hline I & 70 \\
\hline II & 75 \\
\hline III & 78 \\
\hline
\end{tabular}

Berdasarkan hasil tes kemampuan pemahaman konsep siswa terlihat bahwa rata-rata kemampuan pemahaman konsep siswa mengalami peningkatan dari siklus I, ke siklus II dan dari siklus II ke siklus III. Peningkatan ini didukung oleh aktivitas siswa dalam pembelajaran yang semakin baik. Siswa semakin bersemangat untuk mengikuti pembelajaran dan semakin semangat untuk menyelesaikan permasalahan-permasalahan yang diberikan melalui LKPD. Selain LKPD 
mereka juga diberikan handout materi statistika. Handout langsung diberikan untuk setiap siklus bertujuan agar siswa sudah memiliki gambaran untuk materi pada pertemuan dalam siklus tersebut, dan lebih siap untuk mengikuti pembelajaran. Dengan menggunakan LKPD dan handout dalam pembelajaran berbasis masalah aktivitas siswanya semakin baik.

Sebelum pembelajaran dimulai perlu disiapkan: 1) Rencana Pelaksanaan Pembelajaran untuk 8 kali pertemuan dengan menggunakan model pembelajaran berbasis masalah; 2) handout materi statistika; 3) LKPD materi statistika; 4) tes evaluasi akhir siklus I, II dan III; dan 5) jurnal refleksi pembelajaran. Pembelajaran dilaksanakan dalam 8 kali pertemuan yang dijadikan ke dalam 3 siklus. Pada siklus I terdiri dari 4 pertemuan; siklus 2 dan 3 masing-masing terdiri dari 2 pertemuan. Diakhir setiap siklus dilaksanakan tes evaluasi untuk mengukur kemampuan pemahaman konsep siswa. Berikut jadwal pelaksanaan untuk setiap pertemuan:

Tabel 2. Rata-rata pemahaman konsep tiap siklus

\begin{tabular}{crl}
\hline Siklus & Rata-rata & \multicolumn{1}{c}{ Materi } \\
\hline 1. & $29 / 08 / 2018$ & $\begin{array}{l}\text { Konsep Dasar Statistika } \\
\text { (Penyajian Data) }\end{array}$ \\
\hline 2. & $30 / 08 / 2018$ & $\begin{array}{l}\text { Tabel } \\
\text { Frekuensi }\end{array}$ \\
\hline 3. & $31 / 08 / 2018$ & Mean dan Modus \\
\hline 4. & $03 / 09 / 2018$ & Median \\
\hline $\mathbf{5 .}$ & $06 / 09 / 2018$ & Quartil dan Desil \\
\hline $\mathbf{6 .}$ & $07 / 09 / 2018$ & Persentil \\
\hline 7. & $12 / 09 / 2018$ & Jangkauan \\
& & Simpangan Rata-Rata \\
\hline $\mathbf{8 .}$ & $13 / 09 / 2018$ & Variansi dan Standar \\
& & Deviasi
\end{tabular}

Berikut gambaran secara singkat pelaksanaan pembelajaran menggunakan model pembelajaran berbasis masalah:

Pembelajaran diawali dengan pengkodisian siswa baik secara fisik ataupun secara psikis. Diawali dengan berdoa dan menyiapkan bahan dan alat pembelajaran yang akan digunakan. Setelah pengkodisian disampaikan tujuan dan manfaat dari materi yang akan dipelajari. Penyampaian ini sekaligus mengarahkan siswa dalam orientasi pada masalah. Hanya saja pada pertemuan 1 dan 2 siklus pertama tujuan pembelajaran tidak tersampaikan secara eksplisit. Pada pertemuan tersebut guru hanya menyampaikan kemanfaatan penyajian data dalam kehidupan dan manfaat penggunaan tabel distribusi frekuensi. Beberapa siswa ditanya berapa kali dalam bulan Agustus mereka tidak masuk sekolah, berdasarkan hasil tersebut kemudian disajikan dalam tabel.

Pada pertemuan-pertemuan selanjutnya tujuan pembelajaran sudah tersampaikan secara eksplisit. Selain penyampaian tujuan, pada tahap awal pembelajaran guru selalu memotivasi siswa tentang pentingnya mempelajari staistika dan dampak jika tidak memiliki kemampuan statistika yang baik. Dalam tahap orientasi pada masalah tidak hanya menyampaikan kemanfaatan dari materi yang dipelajari, tetapi terkadang menggunakan materi prasyarat yang telah dipelajari sebelumnya untuk memahami materi yang akan dipelajari pada pertemuan tersebut. Sebagai contoh pada pertemuan 2 telah dipelajari tentang tabel distribusi frekuensi, materi ini digunakan sebagai orientasi pada pertemuan ketiga tentang mean dan modus. Contoh lain pada pertemuan 4 tentang median, digunakan sebagai orintasi pada masalah untuk materi quartil dan desil. Materi desil 
digunakan sebagai orientasi pada masalah pada materi persentil. Begitu juga pada materi jangkauan antar quartil dan simpangan quartil, menggunakan quartil data tunggal sebagai orientasi pada masalah.

Setelah orientasi pada masalah, kemudian siswa dibimbing baik secara klasikal maupun individu untuk menyelesaikan permasalahan yang ada di dalam LKPD. Proses pemecahan masalah ini dilaksanakan secara kelompok baik dengan teman sebangku ataupun berdiskusi dengan teman yang lainnya. Pada tahap ini guru berkeliling kelas sambil membimbing jika ada siswa yang merasa kesulitan dalam memecahkan permasalahan yang diberikan. Proses pemecahan masalah ini terkadang mengalami beberapa hambatan, diantaranya: mereka paham tentang konsep yang akan digunakan untuk menyelesaikan permasalahan, akan tetapi mereka kesulitan dalam perhitungan, terutama yang melibatkan pecahan; beberapa siswa merasa kesulitan dalam pembagian bilangan; beberapa siswa menggunakan bantuan kalkulator yang ada di HP untuk menghitung.
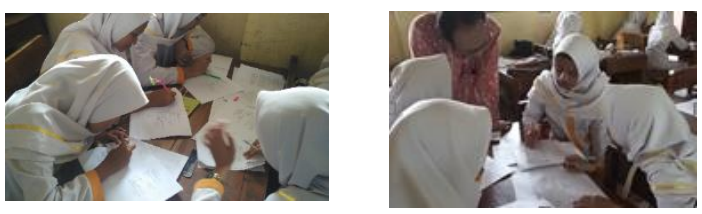

Gambar 1. Diskusi dan pembimbingan

Tahap selanjutnya adalah penyajian dan presentasi hasil. Tahap ini siswa diberikan kesempatan untuk menyajikan hasil penyelesaian pemecahan masalah. Pada pertemuan siklus 1, mereka terlihat tagu-ragu dan malu ketika diminta menyajikan masalah di papan tulis. Setelah ditunjuk, mereka baru bersedia untuk menyajikan masalah. Pada siklus 2 dan 3, mereka sudah mulai berani menyajikan masalah di papan tulis tanpa harus ditunjuk. Begitu juga ketika diminta untuk menceritakan tentang solusi yang disajikan, mereka terlihat masih ragu-ragu dan malu-malu. Tidak semua penyajian hasil yang dituliskan siswa selalu benar, ada beberapa siswa memberikan solusi yang salah. Sebagai contoh, pada saat siswa mengerjakan desil pada pertemuan kelima siswa salah dalam menetukan kelasnya. Hal ini berakibat solusi yang diberikan menjadi salah. Begitu juga pada saat menghitung rata-rata data tunggal, ada siswa yang salah menuliskan rumus yang digunakan. Siswa menuliskan rumus data kelompok untuk menyelesaikan data tunggal.

Melihat hasil penyajian siswa, kemudian dilakukan penguatan dan penekanan untuk hal-hal penting dari materi sampai penarikan kesimpulan. Pada pertemuan ke-6, melalui pemecahan masalah siswa diajak untuk dapat membuat kesimpulan hubungan antara median, quartil, desil dan persentil. Dengan aktivitas pembelajaran yang telah dilakukan mereka dapat membuat beberapa kesimpulan sebagai berikut: 1) nilai median $=$ quartil $2=$ nilai desil $5=$ nilai persentil 50; 2) nilai quartil $1=$ nilai persentil 25; 3) nilai quartil $3=$ nilai persentil 75 ; 4) nilai desil 1 = nilai persentil 10; dll. Dan di akhir pembelajaran siswa diberikan informasi tentang materi untuk pertemuan selanjutnya, Hal ini bertujuan agar siswa membaca terlebih dahulu materi yang akan dipelajari pada pertemuan selanjutnya. Terkadang di akhir pembelajaran siswa diberikan tugas untuk dikerjakan di rumah. Tugas ini sebagai bahan apersepsi pada pertemuan selanjutnya. Hal ini dilakukan seperti pada pertemuan ke 5 tentang quartil dan desil, siswa diberikan tugas rumah tentang desil, dan pada pertemuan selanjutnya soal tentang desil tersebut digunakan sebagai orientasi pada masalah pada pertemuan ke 6 tentang persentil. 

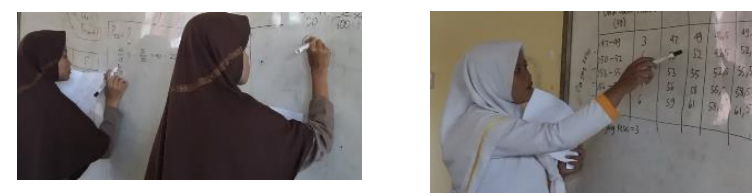

Gambar 2. Penyajian dan presentasi hasil

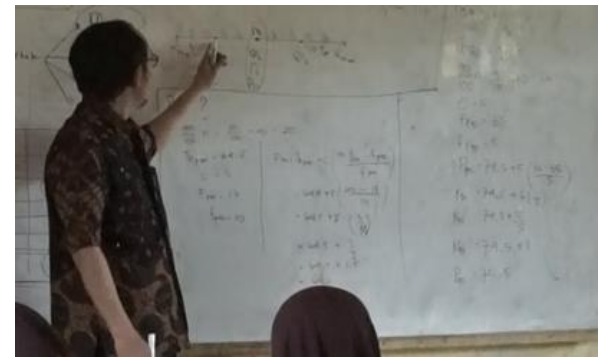

Gambar 3. Penyimpulan

Berdasarkan hasil observasi selama pembelajaran dari siklus 1 sampai siklus 3 terlihat bahwa siswa terlihat yang siswa semakin baik pemahaman konsepnya. Siswa yang awalnya beranggapan bahwa harus menghafalkan banyak rumus untuk dapat menyelesaikan permasalahan tentang median, quartil, desil dan persentil. Mereka mulai menyadari, bahwa mereka tidak perlu menghafalkan semua rumus, tetapi mereka cukup memahami rumus median untuk dapat menyelesaikan persoalan tentang quartil, desil dan persentil. Hal ini ditunjukan dari hasil observasi pada saat pembelajaran, ketika pada pertemuan 4 mereka mampu menyelesaikan median, maka pada pertemuan 5 tentang quartil dan desil, serta pertemuan 6 tentang persentil mereka tanpa kesulitan dapat memahami materi dan menyelesaikan permasalahan yang diberikan.

Beberapa kelemahan siswa yang terlihat dalam pembelajaran diantaranya siswa sudah mulai mampu memahami konsep materi yang diajarkan, hanya saja ketika pada proses perhitungan melibatkan hasil bilangan desimal, mereka terlihat kurang percaya diri untuk menyelesaikannya. Hal ini terlihat pada saat menghitung, beberapa siswa langsung menggunakan HP untuk melakukan perhitungan. Beberapa siswa juga mengaku merasa kesulitan untuk melakukan pembagian menggunakan paragapet.

Sedangkan terkait aktivitas guru dalam pembelajaran juga semakin baik, pada siklus pertama pertemuan 1 dan ke-2 berdasarkan catatan refleksi pembelajaran terlihat bahwa tujuan pembelajaran belum tersampaikan dengan jelas, masih kurang dalam membimbing siswa pada saat kerja kelompok, dan perlu adanya penekananpenekanan pada saat menarik kesimpulan. Temuan lain pada pertemuan ke-4, siswa masih terlihat malu-malu ketika harus mempresentasihan jawaban yang telah dituliskan dipapan tulis.

Hasil observasi dan evaluasi di atas dijadikan sebagai bahan refleksi untuk perbaikan pada pembelajaran berikutnya. Beberapa perbaikan yang dilakukan oleh guru adalah sebagai berikut: 1) di awal pembelajaran siswa diberikan penekanan tentang tujuan dari materi yang akan dipelajari; 2) perlu adanya pendampingan ke setiap kelompok pada saat pembelajaran dan ditanyakan tentang kesulitan-kesulitan yang dialami oleh setiap kelompok; 3) perlu dimotivasi dan kesempatan lebih banyak lagi dalam proses penyajian hasil karya; 4) perlu didesain soal-soal dari tingkat mudah ke yang sulit, dari perhitungan sederhana ke perhitungan yang kompleks; dan 5) di akhir pembelajaran perlu ditekankan tentang hal-hal penting yang dipelajari pada saat pembelajaran.

\section{KESIMPULAN}

Berdasarkan hasil dan pembahasan di atas dapat dikatakan bahwa pembelajaran berbasis masalah dapat meningkatkan 
kemampuan pemahaman konsep siswa. Hal ini ditunjukkan dengan adanya peningkatan nilai rata-rata kemampuan pemahaman konsep siswa dari siklus 1 ke siklus berikutnya.

\section{DAFTAR PUSTAKA}

Abdullah, dkk. 2010. The Effects of Problem Based Learning on Mathematics Performance and Affective Attributes in Learning Statistics at Form Four Secondary Level. Procedia Social and Behavioral Sciences 8. International Conference on Mathematics Education Research. pp. 370-376.

Barbara. 2001. Frequently Asked Questions About Problem-Based Learning. ASCD. Virginia. USA.

Cahyo, A. 2013. Panduan Aplikasi Teoriteori Belajar Mengajar Teraktual dan Terpopuler. Yogyakarta : Diva Press

Huda, M. 2013. Model-model Pengajaran dan Pembelajaran. Yogyakarta: Pustaka Pelajar.

Peraturan Dirjen Dikdasmen No. 506/C/PP/2004

R.D. Padmavathy, Mareesh. K. 2013. Effectiveness of Problem Based Learning In Mathematics. International Multidisciplinary eJournal. Vol II, Issue I, pp 45-51.

Santrock, J.W. 2010. Psikologi Pendidikan Edisi 2. Jakarta: Kencana.

Shadiq, F. 2009. Diklat Insrtuktur Pengembang Matematika SMA Jenjang Lanjut: Kemahiran Matematika. Yogyakarta: Pusat Pengembangan dan Pemberdayaan Pendidik dan Tenaga Kependidikan Matematika.

Sudijono, A. 2009. Pengantar Evaluasi Pendidikan. Jakarta: PT Raja Grafindo Persada.
Sumarmo, U. (2010). Berfikir dan Disposisi Matematik: Apa, Mengapa, dan Bagaimana Dikembangkan Pada Peserta Didik. Jurnal FMIPA UPI Bandung.

Sutawidjaja, A, Jarnawi, 2011. Pembelajaran Matematika. Universitas Terbuka.

Tan. 2009. PBL and Creativity. Cengage Learning. Singapura.

Wardhani, S. 2008. Paket Fasilitas Pemberdayaan KKG/MGMP Matematika. Yogyakarta: Pusat Pengembangan dan Pemberdayaan Pendidik dan Tenaga Kependidikan Matematika. 